\title{
ANNOTATIONS
}

\section{BACTERIOLOGICAL NOTES}

\section{Complement fixation test for gonorrhoea}

The following minor alterations in technique are recommended to all those serologists who use Price's method.

As a result of experience it has been found that the addition of an extra volume of saline to every tube of the antigen titration, complement titration and test proper facilitates the reading of results. This, it is believed, prevents by means of dilution an agglutination of the red cells due to the relatively great amount of serum employed in the test.

In the antigen titration a third row is added, which does not contain serum but contains antigen, saline (two volumes) and complement. From the readings obtained from this row the anticomplementary of the antigen alone is estimated.

\section{A war-time medium for the gonococcus}

This medium was evolved as a result of the shortage of egg albumin.

The base is agar broth (as used in egg albumin agar) (Price ${ }^{1}$ ) to which is added treated human serum. This human serum is collected from the excess of serum left over from blood specimens after the various serum reactions have been completed.

To the serum is added an equal volume of saline and each 10 cubic centimetres of this mixture is treated with 1 cubic centimetre of $\mathrm{N} / \mathrm{NaOH}$. The flask containing the alkali-serum-saline mixture is then put into a saucepan containing cold water ; the temperature is raised to $90^{\circ} \mathrm{C}$. and kept there for 2 hours. Subsequently, after 30 minutes at boiling point, the contents of the flask are cooled down to room temperature. To every 10 cubic centimetres of the mixture 1 cubic centimetre of human serum specially prepared for egging up purposes (Price ${ }^{2}$ ) is added. When it is thoroughly mixed the $p \mathrm{H}$ is adjusted to $5.4-5.6$ by using $\mathrm{N} / \mathrm{HCl}$. Bromcresol purple is the indicator employed and at the specified $p \mathrm{H}(5 \cdot 4-5 \cdot 6)$ a steel-greenish fluorescent colour is obtained. The flask is then returned to a saucepan containing boiling water and within 10-20 minutes egging up takes place. A loose clot floating in a clear straw-coloured fluid is obtained. Should the egging up be delayed beyond 20 minutes it is an indication that more acid is required-usually not more than from 0.5 to 1 cubic centimetre to from 250 to 500 cubic centimetres of the mixture. The egged-up fluid is then filtered through chardin paper and the $p \mathrm{H}$ adjusted to $7 \cdot 3$ (phenol red) before it is sterilized by heat. To make the finished medium add 1 cubic centimetre of the treated human serum to 4 cubic centimetres of agar broth $(p H 7 \cdot 5)$. The result is a clear solid medium on which the gonococcus will grow in primary culture or subculture with equal facility.

I. N. ORPWOOD PRICE, M.R.C.S., L.R.C.P., D.P.H.

\section{REFERENCES}

Price, I. N. O. (1935') J. Path. Bact., 40, 345.

- (1944²) Brit. J. vener. Dis., 20, 45.

\section{Treatment of gonorrhoea by means of penicillin}

On 1st September 1944 the United States of America War Department issued information that, as the results of experimental treatment carried on in the Army, 64 out of 65 men treated with single injections of penicillin were cured of gonorrhosa and that subsequent use on a larger scale has confirmed the early findings. Neither the dosage nor the criterion of cure is stated in the memorandum. Experiments were made with an oil-wax mixture in which penicillin particles were suspended.-From a memorandum from the United States Office of War Information, 4th September 1944. 